\title{
'Together in the National Interest': The Rhetoric of Unity and the Formation of the Cameron-Clegg Government
}

\author{
Judi Atkins \\ Department of International Studies and Social Science \\ Coventry University \\ Email: judi.atkins@coventry.ac.uk
}

Following the formation of the Conservative-Liberal Democrat government in May 2010, David Cameron and Nick Clegg sought to persuade party members, the electorate and a sceptical media that their partnership would hold together for the duration of the parliament. Taking as its starting point Kenneth Burke's theory of rhetoric as identification, this article explores the strategies employed by senior Coalition figures to construct and present an image of unity to these different audiences. Of particular concern are appeals to the parties' shared values and to the 'national interest', as well as the narrative of Britain's 'debt crisis'. This narrative served to minimise inter-party divisions by inviting MPs and supporters to unite behind the cause of deficit reduction, in opposition to the 'fiscally irresponsible' Labour Party that had allegedly wrecked the economy. The article concludes by reflecting on the lessons for the partners in a future UK coalition government.

Keywords: coalition government; United Kingdom; rhetoric; ideology; national interest; deficit reduction 


\section{Introduction}

In their first joint press conference since taking office, David Cameron and Nick Clegg offered a 'radical' programme that would mark the beginning of a 'new politics'. This programme, they claimed, was based on the values of freedom, fairness and responsibility and, moreover, would provide Britain with the strong, stable leadership it needed for the long term. ${ }^{1}$ The overriding aim of this press conference was to present a united front, both to the members of the Coalition's constituent parties and to audiences beyond. In particular, the two leaders sought to foster coalition cohesion while reassuring the financial markets and the public that the new government could take the action necessary to tackle Britain's economic problems. Given the novelty of coalition government in the UK, Cameron and Clegg also had to persuade a sceptical media that their partnership would hold together for the duration of the parliament. This show of unity poses considerable challenges to the parties involved, but it is vital in creating the first impressions that will influence perceptions of the Coalition far beyond the formation stage.

This article employs a modified version of Kenneth Burke's theory of rhetoric as identification to address the question of how a new coalition government constructs and projects an image of unity. In brief, Burke holds that identification may be achieved when a speaker links him- or herself with others by appealing to shared values, attitudes or goals. If successful, this discovery of common ground forms the basis of a rapport between speaker and audience, and thus facilitates co-operative action. For the purposes of the article, I distinguish three forms of identification that may be employed to promote and demonstrate coalition unity. They are: ideological, which is based on shared values; instrumental, which is founded on common interests (either extant or rhetorically constructed); and interpersonal, which concerns the relations between individuals or groups. Also relevant is Burke's concept 
of identification through antithesis, which occurs when groups who would otherwise argue among themselves join forces against a common adversary. This is achieved by portraying the enemy in a negative light, while inviting the allies to identify with the aims and values of the in-group. ${ }^{2}$

Using this framework, I examine the strategies employed by senior Coalition figures to invite party members and the wider electorate to identify with the new government. I begin by showing how the partners mobilised the Coalition's guiding principles, which are derived from the ideological platforms of its component parties along with a shared commitment to reduce the size of the state, to invite identification. Next, I explore how the rhetorical constructions of a 'new politics' and the 'national interest' were employed to downplay partisan interests and quell dissent. I then consider the Coalition's use of identification through antithesis, which is based on a narrative of Britain's debt crisis. This narrative served to unite party supporters behind the common cause of deficit reduction, in opposition to the 'incompetent' and 'fiscally irresponsible' Labour Party. By way of a conclusion, the article reflects on the lessons for a future UK coalition government.

\section{Ideological identification and shared values}

Following the formation of the Coalition, writes Simon Lee, Cameron and Clegg 'sought to demonstrate that their partnership was born out of genuine political conviction rather than an expedient marriage of convenience'. To this end, both leaders employed rhetorical invention to frame the compromises made during the negotiations in a positive light, rather than as the dilution of their parties' cherished commitments. As Cameron puts it, 'the more we talked, the more we listened, the more we realised that our visions for this country and the values that inspired them are strengthened and enhanced by the act of the two parties coming 
together'3. Such displays of ideological identification were central to the construction of an image of unity, which was intended to reassure the party faithful and the electorate that the partners could work well together and, moreover, that the Coalition would stay the course.

The influence of the two parties' ideological traditions is evident in the guiding principles of the Coalition. While a commitment to freedom is common to both, fairness is primarily associated with the Liberal Democrats and responsibility with the Conservatives. At the press conference for the launch of the Programme for Government ${ }^{4}$, senior Coalition figures invited identification with these values, and I examine each concept is in turn. For Clegg and the Conservative Home Secretary, Theresa May, freedom is defined in terms of individual choice and empowerment. In Clegg's words, 'we will disperse power and restore freedom, and so build a stronger society where people are once again trusted to take control of their own lives'. This is a definition with which Conservatives and Liberal Democrats would readily identify and, in practice, it entails a better balance between individual freedom and national security, together with the restoration and protection of our civil liberties. As we will see below, the parties' shared belief in freedom from state control also supplies the ideological basis for significant reductions in public expenditure.

Meanwhile, the Business Secretary, Vince Cable, explained that fairness is about 'being a society where we protect the weakest, the most vulnerable and where everybody has the opportunity to fulfil their potential'. Indeed, he claimed, 'without agreement on ... the concept of fairness, the coalition would never have happened'. This statement is critical because Cable is associated with the social democratic tradition within the Liberal Democrats. As such, his presence in the new government offers reassurance that these values will be upheld and acted upon, and thus invites the left wing of the Party to identify with the Coalition and to support its policy programme. Such reassurance was important, as the Liberal Democrat leadership had recently come to accept the Conservatives' plan for tackling 
Britain's budget deficit. While Cable noted that this was the Coalition's first priority, he was quick to emphasise that:

The success of the government won't simply be measured by whether we deal with the budget deficit, but how we deal with it ... And the approach is that the burdens have got to be fairly shared - and in the difficult times ahead, we won't balance the books on the backs of the poorest.

Although fairness is a core Liberal Democrat value, Cable's use of the pronoun 'we' implies that both party leaderships are identified with this commitment and, furthermore, that it will guide the Coalition's deficit reduction programme.

On Cameron's view, the most important of the three principles is responsibility, as it is a core Conservative value and the mainstay of the 'Big Society'. This concept is explicated by Cameron and George Osborne at the launch of the Programme for Government, which reflects both their ideological identification and the Conservatives' status as the senior partner within the Coalition. Cameron defines responsibility in terms of the obligations we owe to each other, the fulfilment of which will supply the foundations of a strong society. Equally, he continues, those who are unable to play their part will receive the help they need. This statement is consistent with the Liberal Democrats' belief in fairness, and so invites identification with Cameron as the embodiment of a modernised, compassionate Conservative Party that will promote responsibility while protecting the vulnerable.

Whereas Cameron focuses on social responsibility, Osborne, as Chancellor, is primarily concerned with the economy. Thus, he pledged that 'this coalition will put everything it does through this simple test: if it encourages responsibility we should do it; if it encourages irresponsibility, we shouldn't'. In particular, he continued, 'we will bring responsibility to ... creating a new economic model, where we save and invest for the future instead of building an economy on debt'. This promise is mainly targeted at Conservative 
supporters but, in the wake of the 2008 global economic crisis, the notion of financial responsibility also resonates with a wider audience. By tapping into this, Osborne invited the public to identify ideologically with the Coalition, while seeking to cultivate an image of economic competence.

Underlying the Coalition's guiding principles is a belief in a smaller state, which facilitated the discovery of common ideological ground between the two parties and, moreover, affords them a means of promoting their goals of freedom and responsibility. For Clegg, the dispersal of state power will ensure that people are 'free to make their own choices', while Cameron and Osborne view cuts to public spending - notably to the welfare budget - as vital to fostering personal and social responsibility. However, it would soon become apparent that the retrenchment of the social democratic state was at odds with the Coalition's publicly-expressed commitment to fairness. As Libby McEnhill demonstrates in her paper, the Liberal Democrats could respond either by publicly reaffirming their belief in this core value, so preserving their distinctiveness, or by maintaining coalition unity at the expense of their reputation as the party of social justice. That they chose the second option led to ideological conflict within the Liberal Democrats and, in the longer term, caused serious damage to the party's public image and electoral prospects alike.

Although values are undoubtedly important, Cameron asserts that, 'above all, [the Coalition is] united in the purpose of bringing strong, stable, decisive government to our country'. This, he claims, is 'something that all Conservatives believe in profoundly', and as such his statement invites MPs and party supporters to identify ideologically with the Coalition. It can also be interpreted as an attempt to carve out a place for the Coalition within the myth of the British political tradition, according to which strong, effective (single-party) government is intrinsically desirable, and so to reassure a wider audience that the partnership will not collapse within months. Either way, Cameron's words suggest that his administration 
is ideologically identified, that it is united by shared values as well as a common goal, and that therefore it will endure.

\section{Instrumental identification and the 'national interest'}

The Coalition's stated aim of providing strong, stable government is closely linked to the idea of the national interest. In Cameron's words, 'given the massive challenges this country faces, particularly the deficit, the national interest was not served by a minority government limping along. It was served by strong, stable, decisive government that could really act in the long-term interests of our country'. Likewise, Clegg stated that 'at a time of such enormous difficulties, our country needed a strong and stable government. It needed an ambitious government determined to work relentlessly for a better future. That is what we have come together in this coalition to provide'. ${ }^{5}$ These claims indicate that the two leaders had agreed on a definition of the problems facing Britain, and had also attained instrumental identification based on a mutually acceptable conception of the 'national interest'. Indeed, their vision of the 'national interest' may afford a useful means of transcending ideological conflict and partisan interests, and so provides an alternative basis for identification.

In addition to bringing stability, Clegg claimed, the Coalition will be a 'radical reforming government' where needed. As such, it will usher in a 'new politics' where, as Cameron puts it, 'the national interest is more important than the party interest, where cooperation wins out over confrontation, where compromise ... is not a sign of weakness, but a sign of strength'. It is worth noting that both leaders emphasise the novelty of the Coalition's approach, portraying it as a departure from the in-fighting of previous governments and as a source of hope for the future. ${ }^{6}$ This representation is designed to create a sense of optimism, 
which will increase the receptivity of their audience to the idea of a 'new politics' and, in turn, promote identification with the Coalition itself.

Cameron and Clegg present the rapport between them as exemplary, as standing for the 'new politics' as a whole. Thus, Cameron emphasised their shared desire to 'put aside party differences and work hard for the common good and for the national interest', while Clegg observed that "we have just been through an election campaign and now we have a coalition. Until today, we were rivals; now, we are colleagues. That says a lot about the scale of the new politics that is now beginning to unfold'. ${ }^{7}$ On one level, these displays of interpersonal identification enable the two leaders to project an image of coalition unity. On another, Cameron and Clegg's changed relationship provides a model for their MPs to emulate, encouraging them to overcome partisan rivalry and co-operate with their former adversaries to deliver the strong, stable government Britain needed.

The allocation of ministerial portfolios is a source of potential conflict for any government, but arguably more so for a coalition. In a bid to neutralise discontent among backbench MPs, Cameron explained that:

There are five Liberal Democrat Secretaries of State in Cabinet working hand in hand with Conservative colleagues to address the big challenges that Britain faces ... I think this is a sign of the strength and depth of this coalition and our sincere determination to work together constructively to make this coalition work in our national interest. $^{8}$

This depiction of inter-party co-operation within the Cabinet again serves as an example to MPs, inviting them to set aside any ill-feeling and identify with Cameron's conception of the national interest. After all, any open dissent at this early stage could be construed as an expression of narrow self-interest that would damage MPs personally and, moreover, risked destabilising the Coalition at a time when unity was paramount. 
At the launch of the Programme for Government, Clegg addressed the electorate directly:

New politics is about delivering the change you want ... You will get a referendum on the voting system, so you have a greater say on who represents you in Parliament. Government will be transparent. You will be able to get your hands on all the information you need. You will be able to sack MPs who abuse the rules and we will pass a Freedom Bill to restore and protect your liberties.

Here, Clegg invited the public to identify instrumentally with the Coalition by enumerating the positive changes the 'new politics' will bring to their lives. After acknowledging the scale of the economic challenges facing Britain, he frames deficit reduction as the precondition for the Coalition's 'ambitious programme for change and renewal'. More specifically, austerity is presented as the means for achieving its goals of 'a stronger society, a sound economy, an accountable state, and power and responsibility in the hands of every citizen', and thus as in the national interest. ${ }^{9}$ I return to this argument in the next section.

There were, of course, individual and partisan interests involved on both sides, but they were downplayed by the two leaders in their efforts to portray the Coalition as a strong, united partnership. For Cameron, the formation of the coalition enabled him to deflect attention from his failure to win an overall majority and, in the words of Timothy Heppell and David Seawright, to 'minimise the impact of opposition from the parliamentary right [of his party] by diluting it with the support of the Liberal Democrats'. More broadly, Ben Yong notes that the Conservatives could not have enacted their austerity programme as a minority government, and so needed to be the larger party in a coalition. From the Liberal Democrats' perspective, meanwhile, Ruth Fox notes that the parlous state of their finances 'meant that the party could not afford a quick second election'. ${ }^{10}$ They also needed to show that coalition politics could work, given their longstanding commitment to electoral reform and their desire 
to secure a 'Yes' vote in the forthcoming referendum on the Alternative Vote. To voice these concerns in public would have risked making the leaders' decision to form a coalition appear self-serving, so they instead framed partnership government as the only means of advancing the national interest at a time of great uncertainty, and invited instrumental identification on this basis.

\section{Identification through antithesis: The deficit narrative}

The Coalition's 'crisis narrative' is built around the structural deficit and is employed to invite identification through antithesis. This narrative consists of two parts - a common cause and a common enemy - and I consider them in turn. As Paul 't Hart and Karen Tindall correctly point out, political parties will 'seek to mould and exploit ... crises in ways that suit their interests' and, I add, are compatible with their values and goals. Thus, in their 2010 manifestos, the Conservatives and the Liberal Democrats framed Britain's ongoing economic problems as a 'crisis of debt' that necessitated measures to reduce public expenditure. This response would have been seen as likely to compound the nation's difficulties had the situation been framed as a 'crisis of growth', but it appears an entirely logical solution to a 'debt crisis'. ${ }^{11}$ As a result, the parties' claims that cuts to government spending are in the national interest were more likely to gain traction with a wider audience.

On entering into coalition, the development of a single narrative was facilitated by the ideological similarities between Conservative modernisers and the Orange Book Liberal Democrats. Of particular importance are the values of individual freedom and a smaller, less centralised state, which both factions believe can be realised through reductions in public expenditure. As Matt Beech explains, the idea is that the 'retrenchment of the state will gradually enable entrepreneurs and private firms to engender growth and for the voluntary 
sector and businesses to begin to provide more goods and services to the British people where previously the state had dominated'. ${ }^{12}$ The congruence of the two parties' thinking ensures that the commitment to austerity acts not only as the cornerstone of the Coalition, but as the overarching goal that will sustain the partnership through the inevitable conflicts and compromises ahead.

According to the Programme for Government, 'the deficit reduction programme takes precedence over any of the other measures in this agreement'. This primacy is framed in terms of the national interest, with Cable supporting the immediate implementation of austerity on the ground that 'the problem of the financial crisis in Europe over the last few weeks has underlined the absolute priority for establishing confidence in the country'. Cable's statement marked a startling about-face for the Liberal Democrats, who had campaigned vigorously against immediate spending cuts before the general election. On this basis, Mark Stuart suggests that the Party may have used the emerging Eurozone crisis as a fig leaf to justify their acceptance of the Conservatives' economic policy and the subsequent formation of a full coalition government. It is also worth noting Andrew Gamble's claim that senior Coalition figures exaggerated the threat this developing crisis posed to Britain 'in order to establish a new definition of political reality and a new set of policies' ${ }^{13}$ Nevertheless, the alignment of core party values with the leaders' conception of the national interest constituted a compelling invitation to MPs and grassroots members to identify with the Coalition, and so unite behind the cause of deficit reduction.

In bringing the parties together to tackle the economic crisis, the narrative also joined them together against a common enemy, namely the Labour Party. Paul 't Hart and Karen Tindall explain that 'apportioning blame is an integral part of contemporary politics in times of crisis' and, given that the financial crash occurred on Labour's watch, it was relatively 
easy for the coalition partners to hold them responsible. To this end, writes Ben Kisby, Coalition figures have repeatedly claimed that:

The vast government debt that now needs to be tackled is the result of an over-mighty state and not due to the previous government's need to spend hundreds of billions of pounds precisely to prop up banks and the money markets to enable the free market to keep functioning.

Thus, through rhetorical invention, the Labour government's fiscal stimulus, which as Gamble notes was previously seen as the 'necessary means to avoid financial collapse', is redefined as the problem that the Coalition needs to overcome in order to restart economic growth. ${ }^{14}$

To further undermine Labour's reputation, Coalition figures attribute the crisis not only to its alleged incompetence and mismanagement, but to moral failure. As Osborne puts it:

So many of the great problems we face as a country today ... come back to a lack of responsibility. Our enormous debts, our massive welfare rolls ... at the root of these problems may be one person, a collection of people, or even a whole culture, saying, "Let's do what we want, instead of what is right".

In contrast, he continues, the Coalition will bring responsibility 'back to the heart of our national life' by reducing the size and power of the state, reforming the welfare system, and demonstrating that Britain can 'tackle its debts and live within its means' ${ }^{15}$ The suggestion here is that because responsibility is one of the Coalition's guiding principles, it alone can be trusted to act in the national interest and take the difficult decisions required to transform the economy and restore sustainable growth. In this way, identification through antithesis served to minimise inter-party divisions by inviting MPs and supporters to unite behind the values 
and goals of the Coalition, in opposition to the 'fiscally irresponsible' Labour Party that had 'wrecked' Britain's economy.

However, writes Stuart, 'what [the Liberal Democrats] seemed unable to realise at the time was that their central concession to the Conservatives on the economy - agreeing to cut the deficit further and faster than Labour - trumped all their anorak manifesto commitments put together'. It also came at the cost of their commitment to fairness which, as noted above, was subordinated to the Coalition's goal of reducing the size of the state. Although a degree of ideological realignment may be inevitable for the junior coalition partner, a process that was facilitated in this case by the proximity of the Conservative leadership and the Orange Book Liberal Democrats, the latter could arguably have defended their core principle more vigorously. After all, claims Stuart, the Conservatives 'needed the maximum degree of parliamentary support possible for [their] tough decisions on public spending ... [and

calculated that] the best means of securing that was through a strong and stable coalition'. ${ }^{16}$ This suggests that the Liberal Democrats could have demonstrated more influence over the direction of the government than they perhaps believed possible, and that they could have done so without fear of the partnership's collapse. But, in the early days of the new government - and in public at least - the two parties needed to present a united front; there would be plentiful opportunities for them to assert their distinctiveness later on.

\section{Conclusion and lessons for a future UK coalition government}

To conclude, this article has examined the rhetorical strategies employed by Coalition figures to invite identification with the values and goals of the new government, and so to construct and present a united front. This process was facilitated by the discovery of common ground between Conservative modernisers and the Orange Book Liberal Democrats, which enabled 
ideological identification to occur. However, this proximity made it difficult for the Liberal Democrats to maintain their distinctive identity, while their acceptance of the Conservatives' austerity agenda has done serious damage to their image as the party of social justice. Differentiation is nearly always a problem for the junior partner, but it is an important means of preserving credibility and maintaining trust. Consequently, the smaller party in a future coalition must be wary of sacrificing too many of its core values for the sake of demonstrating government unity.

The discovery of ideological common ground is likely to be problematic for, say, a potential Conservative-SNP or Labour-UKIP pairing (unlikely though these may be). As such, a combination of careful pre-election planning and the skilful use of invention would be required to make it work. The technique of instrumental identification may prove invaluable in such situations, as it affords the parties an alternative means of presenting a united front to a wider audience. For Cameron and Clegg, it enabled them to frame the Coalition as the 'new politics' that placed the national interest before partisan concerns and, moreover, would give Britain the strong, stable government needed to overcome the challenges ahead. The case of the Conservative-Liberal Democrat government also highlights the power of appeals to the 'national interest' in quelling dissent over matters such as the allocation of ministerial portfolios, as MPs risk appearing self-interested and petty if they openly criticise the coalition leadership at such an early stage.

In addition to these strategies, senior Coalition figures employed identification through antithesis to bring the two parties together in opposition to Labour. This is the function of the deficit narrative, in which immediate reductions in public expenditure were framed as consistent with not only the Coalition's commitments to freedom and responsibility, but with the leadership's conception of the 'national interest'. Meanwhile, Britain's problems are blamed on the previous Labour government, whose allegedly reckless 
spending had destroyed the economy and necessitated the Coalition's austerity programme. However, the Liberal Democrats' willingness to reproduce this narrative will come back to haunt them if the 2015 general election produces a hung parliament with Labour as the largest party. That Ed Miliband has reportedly ruled out a deal with the Liberal Democrats if Clegg remains as leader suggests that sustained, aggressive attacks on the Opposition should perhaps be left mostly to the senior partner, as the smaller party may later be confronted by the prospect of coalition talks with the former adversary.

Despite early predictions to the contrary, and conflicts over issues such as constituency boundary changes and the EU, the Coalition has lasted for a full five-year term. Although the establishment of formal and informal machinery for resolving disputes was undoubtedly important, it is perhaps not too much of a stretch to suggest that rhetorical strategies also had a role to play in keeping the partnership together. By invoking values, goals, the 'national interest' and a common enemy, senior Coalition figures were able to invite identification on a variety of grounds, and thus to appeal to multiple audiences. Beyond the formation stage, this approach may have created the possibility of identification changing over time. So, an individual who initially identifies with the Coalition's ideological commitments may later come to identify primarily with its antipathy towards Labour. It is likely that the provision of several bases for identification contributed to the longevity of the Conservative-Liberal Democrat partnership, and indeed that the use of similar rhetorical strategies would be similarly beneficial to the parties in a future coalition government.

\footnotetext{
${ }^{1}$ D. Cameron and N. Clegg, Press Conference given by Prime Minister David Cameron and Deputy Prime Minister Nick Clegg, 12 May 2010.
} 
${ }^{2}$ On rhetoric as identification, see K. Burke, (1969) A Rhetoric of Motives, Berkeley and Los Angeles, CA: University of California Press, 1969. For Burke's account of identification through antithesis, see his Dramatism and Development, Barre, MA: Clark University Press, 1972, p. 28.

${ }^{3}$ S. Lee, “We Are All in This Together": The Coalition Agenda for British Modernisation', in S. Lee and M. Beech (eds) The Cameron-Clegg Government: Coalition Politics in an Age of Austerity, Basingstoke: Palgrave Macmillan, 2011, p. 13; D. Cameron, Press Conference on The Coalition: Our Programme for Government, 20 May 2010.

${ }^{4}$ All references in this section are to N. Clegg, T. May, V. Cable, G. Osborne and D. Cameron, Press Conference on The Coalition: Our Programme for Government, 20 May 2010.

${ }^{5}$ D. Cameron, Press Conference on The Coalition: Our Programme for Government; N. Clegg, Press Conference given by Prime Minister David Cameron and Deputy Prime Minister Nick Clegg.

${ }^{6}$ N. Clegg, Press Conference given by Prime Minister David Cameron and Deputy Prime Minister Nick Clegg; D. Cameron, Press Conference given by Prime Minister David Cameron and Deputy Prime Minister Nick Clegg.

${ }^{7}$ D. Cameron, General election victory speech; N. Clegg, Press Conference given by Prime Minister David Cameron and Deputy Prime Minister Nick Clegg.

${ }^{8}$ D. Cameron, Press Conference given by Prime Minister David Cameron and Deputy Prime Minister Nick Clegg.

${ }^{9}$ N. Clegg, in N. Clegg, T. May, V. Cable, G. Osborne and D. Cameron, Press Conference on The Coalition: Our Programme for Government. 
10 T. Heppell and D. Seawright, 'Introduction', in T. Heppell and D. Seawright (eds), Cameron and the Conservatives: The Transition to Coalition Government, Basingstoke: Palgrave Macmillan, 2011, p. 9; B. Yong, 'The Political Parties', in R. Hazell and B. Yong, The Politics of Coalition: How the Conservative-Liberal Democrat Government Works, Oxford: Hart Publishing Ltd, p. 118; R. Fox, 'Five Days in May: A New Political Order Emerges', p. 610.

${ }^{11}$ P. 't Hart and K. Tindall, "From "market correction" to "global catastrophe": framing the economic downturn', in P. 't Hart and K. Tindall (eds) Framing the Global Economic Downturn: Crisis Rhetoric and the Politics of Recessions, Canberra: ANU E Press, 2009, p. 9; Liberal Democrats, Liberal Democrat Manifesto 2010, London: Liberal Democrats, 2010, p. 14; Conservative Party, Invitation to Join the Government of Britain: The Conservative Manifesto 2010, London: The Conservative Party, 2010, p. 3. On the framing of the 2008 crisis, see C. Hay, 'Treating the Symptom Not the Condition: Crisis Definition, Deficit Reduction and the Search for a New British Growth Model', British Journal of Politics and International Relations, vol. 15, no. 1, 2013, pp. 23-37.

${ }^{12}$ M. Beech, 'A Tale of Two Liberalisms', in S. Lee and M. Beech (eds) The Cameron-Clegg Government: Coalition Politics in an Age of Austerity, p. 273.

13 HM Government, The Coalition: Our Programme for Government, London: Cabinet Office, 2010, p. 35; V. Cable, in N. Clegg, T. May, V. Cable, G. Osborne and D. Cameron, Press Conference on The Coalition: Our Programme for Government; M. Stuart, 'The Formation of the Coalition', in S. Lee and M. Beech (eds) The Cameron-Clegg Government: Coalition Politics in an Age of Austerity, p. 48; A. Gamble, 'Economic Policy', in T. Heppell and D. Seawright (eds), Cameron and the Conservatives: The Transition to Coalition Government, p. 69. 
${ }^{14}$ P. 't Hart and K. Tindall, 'From "market correction" to "global catastrophe": framing the economic downturn', p. 9; B. Kisby, 'The Big Society: Power to the People?' The Political Quarterly, vol. 81, no. 4, 2010, p. 485; A. Gamble, 'Economic Policy', p. 67.

${ }^{15}$ G. Osborne, in N. Clegg, T. May, V. Cable, G. Osborne and D. Cameron, Press Conference on The Coalition: Our Programme for Government.

${ }^{16}$ M. Stuart, 'The Formation of the Coalition', pp. 53, 48. 